This work is licensed under Creative Commons Attribution 4.0 International (CC BY 4.0). [http://creativecommons.org/licenses/by/4.0/]

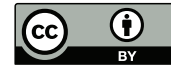

\title{
Metody i formy pracy w szkolnictwie pijarskim
}

Katarzyna Semrau | Uniwersytet Gdański, Wydział Nauk Społecznych https://orcid.org/0000-0002-7289-6913

Słowa kluczowe: pijarzy, wychowanie, edukacja, religia
Keywords:

Piarist, breeding, education, religion

\section{Streszczenie}

W artykule opisano metody i formy pracy z młodzieżą wynikające z działalności zakonu pijarów. Przedstawiono strukturę i organizację zarówno samego zakonu, jak i główne założenia instytucji szkoły pijarskiej. Wskazano także na kiedyś niezwykle innowacyjne a współcześnie popularne aspekty pracy wychowawczej, takie jak humanistyczne podejście do ucznia czy nagradzanie, o których pisał założyciel zakonu Józef Kalasancjusz już w pierwszych wytycznych dotyczących pracy związanej z kształceniem wychowanków. Oferta szkoły regularnej i bezpłatnej, jaką przygotowali pijarscy zakonnicy, była jedną z pierwszych na świecie skierowaną do ubogich dzieci i młodzieży. Poruszono także kwestię przemian zachodzących w zakonie pijarów, gdy - głównie ze względu na efektywność nauczania - placówki te zaczęły się zmieniać i stawać szkołami przeznaczonymi dla elit. Wiele uwagi poświęcono również postaci samego założyciela, jak i najpopularniejszemu polskiemu pijarowi i reformatorowi - Stanisławowi Konarskiemu.

\section{Methods and forms of Piarist education Summary}

The paper reviews forms and methods of youth work incident to the Piarist Order activity and depicts the structure and organisation of both the Order and the main assumptions of the Piarist school institution. Moreover, the article indicates once most innovative and contemporarily popular aspects of pedagogic work, such as humanistic approach to a student or recompensing which the founder of the Order Joseph Kalasancjusz wrote about in guidelines for work related to education of foster children. The offer of regular and free school prepared by the Piarist conventuals was one of the first in the world addressed to poor children and youth. The above-mentioned paper depicts ongoing changes in the Piarist Order, mainly due to the effectiveness of teaching piarist institutions has begun to change and became schools for the elite. Not without significance is the rather thoroughly characterized figure of the founder himself, as well as the most popular Polish piarist and reformer - Stanisław Konarski. 


\section{Wstęp}

Szkolnictwo pijarskie pełniło istotną rolę w propagowaniu idei kształcenia dzieci i młodzieży. Charakterystyczną cechą edukacji w szkołach pijarskich było podmiotowe podejście do wychowanka. Aby lepiej zrozumieć ideę tego typu szkoły, należy zwrócić uwagę na to, jak kształtował się rozwój zakonu i jego historia. Pomimo zmian w strukturze szkoły dotyczących organizacji szkolnictwa, założenia dotyczące metod i form pracy wychowawczej pozostały w formie, jakiej chciał sam założyciel. Szkolnictwo pijarskie doceniane jest także współcześnie, zarówno w Polsce, jak i na świecie. Ze względu na jej ponadczasowy charakter istotna wydaje się analiza założeń pijarskich w odniesieniu do współczesnych praktyk pedagogicznych.

\section{Założenie zakonu}

Jednym z najbardziej znanych pijarów jest sam założyciel: „ogromny wpływ na charakter szkolnictwa pijarskiego wywarł Józef Kalasancjusz, założyciel i dożywotni generał zakonu, którego postać jest wciąż zbyt mało znana, a zasługi dla pedagogiki niedocenione" (Puchowski 1996: 214). Porównywany był przez niektórych do Jana Amosa Komeńskiego, którego określano wychowawcą protestanckiej Europy, natomiast Józefa Kalasancjusza nazywano wychowawcą Europy katolickiej, głównie ze względu na fakt, że był on założycielem pierwszego zakonu, który poświęcił się nauczaniu (Taraszkiewicz 2015: 16).

Józef Kalasancjusz, a właściwie José de Calasanz, urodził się w wiosce Peralta de la Sal w Hiszpanii, prawdopodobnie w 1556 lub 1557 roku (Puchowski 1996: 214). Jego ojciec, Pedro de Calasanz, sprawował funkcję burmistrza, ale z zawodu był ślusarzem (Taraszkiewicz 2011: 14). Gdy Józef poszedł do szkoły w Estadilla, potrafił już czytać i pisać, więc prawdopodobnie nauczył się tego w rodzinnym domu. W wieku piętnastu lat Kalasancjusz zaczął studia prawnicze i filozoficzne na uniwersytecie w Leridzie (Ausz 2013: 20). W wielu dwudziestu lat podjął studia prawnicze w Walencji, a później na uniwersytecie w Huesca. W 1585 roku przyjął święcenia kapłańskie i z czasem osiedlił się na stałe w Rzymie (Puchowski 1996: 215). Początkowo zatrudniony był jako wychowawca bratanków kardynała Antoniego Colonna oraz był członkiem dwóch towarzystw miłosiernych: Arcybractwa św. Apostołów, gdzie pełnił funkcję wizytatora, odwiedzał szkoły dla ubogich oraz był katechetą rzymskich Cyganów oraz Towarzystwa Nauki Chrześcijańskiej. Widząc biedę na ulicach Rzymu, Kalasancjusz zapragnął założyć szkołę przeznaczoną do nauczania ubogich i podjął w związku z tym starania w Senacie Rzymskim i u jezuitów, jednak jego pomysł odrzucono. Sam postanowił więc otworzyć taką szkołę (Ausz 2013: 20-21).

Należy podkreślić, że w Rzymie pod koniec XVI wieku działało tylko czternastu nauczycieli pracujących w płatnych szkołach dla ludu, a Rzym miał wtedy ponad 100 tysięcy mieszkańców. Pomysł Kalasancjusza był więc wyjątkowo innowacyjny, ponieważ 
niewiele osób chciało zajmować się kształceniem ubogich, których uważano wtedy za obywateli gorszej kategorii. Kalasancjusz otworzył więc w dzielnicy Zatybrze w zakrystii kościoła św. Doroty Szkołę Pobożną (Schola pia). Istniała tam wcześniej szkoła, ale była nieregularna i płatna. W założeniach szkoła Kalasancjusza miała być bezpłatna i kształcić ubogich na poziomie elementarnym. Skoro nawet płatne szkoły były wtedy nieregularne, głównie ze względu na małą ilość nauczycieli, pomysł Kalasancjusza wydawał się wtedy szczególnie innowacyjny (Puchowski 1996: 215-216). Szkoła miała być w zamyśle założyciela ratunkiem od biedy, ponieważ człowiek wykształcony może łatwiej znaleźć pracę, a tym samym uchronić się od nędzy: „To dzięki zdobytej wiedzy dziecko miało odkryć własną wartość, własną godność, to dzięki szkole miało zdobyć umiejętności, które pozwalałyby wyrwać się z zamkniętego kręgu biedy" (Wróbel-Lipowa, Ausz 2010: 17). Powyższy cytat świadczy o tym, jak duże nadzieje założyciel pokładał w instytucji szkoły. Traktował ubóstwo jako źródło patologii społecznej. Można więc wysnuć wniosek, że Kalasancjusz traktował szkołę jako formę profilaktyki ogólnej, współcześnie niezwykle istotnej w kontekście wychowania i resocjalizacji.

Jak wspomniano wcześniej, otwarcie bezpłatnej szkoły było pomysłem rewolucyjnym w tamtym okresie. W związku z tym założyciel był wielokrotnie krytykowany i oskarżany o burzenie społecznego ładu (Wróbel-Lipowa, Ausz 2010: 17-18). Jego głównym celem był człowiek, a instytucja szkoły miała być dopasowana do ucznia - właśnie to założenie przez wiele lat było krytykowane i dopiero współczesna pedagogika zgadza się z tego typu podejściem. Założyciel podkreślał także, że dobre wychowanie jest ściśle związane z kształceniem, a z kolei wychowanie jest podstawą możności wyrwania się ze zła, bo dobro postrzegane było przez niego jako oświecenie człowieka. Nowością było także to, że wychodząc z takich założeń, szkoły pijarskie kształciły dzieci różnych wyznań, a nie wyłącznie katolickiego. Przy założeniu szkoły Kalasancjusz spisał documentum princeps w latach 1604-1610 (Puchowski 1996: 216-218). Dokumenty i konstytucje były $w$ trakcie powstawania i trwania zakonu wielokrotnie modyfikowane i przetwarzane, ale główny nacisk kładziony był zawsze na ważną rolę nauczania w wychowaniu. Nauczanie to kształciło w większości na poziomie elementarnym, jednak niezwykle ważnym aspektem było miłosierdzie, którym mieli kierować się nauczyciele względem uczniów.

Rozwój szkoły okazał się niezwykle dynamiczny i po pięciu latach od powstania placówka liczyła ponad 700 uczniów. W związku z tym pojawiły się problemy z pomieszczeniem uczniów, należało rozbudować szkołę, tak aby wszyscy mogli skorzystać z oferty edukacyjnej, co z kolei rodziło problemy finansowe. Brakowało także nauczycieli i wychowawców dla tak dużej grupy uczniów. W 1616 roku powstała druga szkoła w Frascati. W związku z tym założyciel powołał kongregację religijną Scholarum Piarum zatwierdzoną przez papieża Pawła V. Po czterech latach istnienia podniósł on jednak jej rangę i uczynił zakonem mającym śluby uroczyste, którymi były obok ślubu ubóstwa, czystości i posłuszeństwa, także ślub nauczania dzieci i młodzieży. Pełna nazwa zakonu brzmiała Ordo Clericorum Regularium Pauperum Matris 
Dei Scholarum Piarum, czyli Zakon Kleryków Regularnych Ubogich Matki Bożej Szkół Pobożnych (Taraszkiewicz 2011: 16-17).

Wymogi dotyczące przyszłych nauczycieli określił sam Józef Kalasancjusz, do tych podstawowych należały cierpliwość i miłość względem wychowanków, ale podkreślał także, że nauczać może jedynie osoba bardzo dobrze wyszkolona, a nie każdy nauczyciel. Założyciel był otwarty na sugestie innych zakonników, w zakonie panowała bowiem demokracja. Nauczanie w szkołach pijarskich było zbiorowe i odbywało się w ojczystym języku, a uczniowie byli podzieleni na klasy. Nauka w jednej klasie trwała około 3-4 miesiące. W zależności od poziomu nauczano elementarnie, na przykład w pierwszej klasie uczono alfabetu i znaku krzyża, w drugiej czytania (w języku ojczystym), potem pisania, a w kolejnych klasach kaligrafii i podstaw języka łacińskiego. Takie nauczanie miało chronić ubogą i bezdomną młodzież od demoralizacji, miało więc nie tylko szeroki aspekt edukacyjny czy, jak można by się było spodziewać, religijny, ale także, a może przede wszystkim, wychowawczy. Szkoły utrzymywały się z darów pochodzących od darczyńców, ponieważ zakon zrzekł się posiadania nieruchomości i innych dóbr.

Na szczególną uwagę zasługuje Collegium Nazarenum, które powstało w 1630 roku. Zostało założone z myślą o dwunastu ubogich chłopcach mających stać się w przyszłości zakonnikami. Kandydat do tej szkoły musiał najpierw odbyć roczną próbę i dopiero dobrze zaopiniowany mógł przystąpić do szkoły (Taraszkiewicz 2011: 18-20). Kalasancjusz oparł program tej szkoły na wzorze Collegium Romanum, które było uczelnią jezuicką. Zarówno pijarzy, jak i jezuici działali niejako jako konkurencja dla szerzącego się protestantyzmu w tamtym czasie. Działalność pijarska była o tyle znacząca, że wśród głównych zasad, jakimi mieli kierować się zakonnicy, było stałe dokształcanie się poprzez między innymi cotygodniowy udział w konferencjach z udziałem przełożonych i częste tworzenie sprawozdań z działalności. Pijarzy, tworząc taki system kształcenia, nie mogli zapomnieć o szczególnym skupieniu się na metodach i formach pracy wychowawczej. Stosowano więc system kar i nagród z wyraźnym zaznaczeniem, aby nie kierować się zbytnią surowością w karaniu (Taraszkiewicz 2011:28). Także struktura zarządu była w tym zakonie dobrze przemyślana, na jego czele po śmierci Kalasancjusza stał generał, któremu pomagali czterej asystenci i prokurator generalny. Co kilka lat zwoływano kapitułę generała, w której udział brał zarząd główny oraz prowincjałowie z delegatami prowincji (Taraszkiewicz 2015: 19). Początkowo program działania szkoły obejmował 9 klas, jednak uczniowie kończyli klasę, gdy opanowali stosowny materiał, niekoniecznie spędzając w jednej klasie cały rok. Szkolnictwo pijarskie zostało zatem podzielone niejako na dwa poziomy, klasy od drugiej do piątej przygotowywały głównie do podjęcia pracy i służyły nauce zawodu, więc przedmioty miały charakter praktyczny. Po ukończeniu tego poziomu uczniowie byli zdolni do tego, aby iść do pracy i tym samym zarabiać na siebie. Należy pamiętać jednak, że ten okres był poprzedzony pierwszą klasą, w której uczono znaku krzyża, co może świadczyć o tym, że religię postrzegano jako podstawę rozwoju człowieka i jego duchowości. 
Następnie uczniowie, którzy chcieli rozwijać się naukowo i mogli sobie na to pozwolić, kontynuowali edukację w kolejnych klasach. Cały system opierał się na idei nauki i pobożności, a zajęcia trwały cały dzień. Główną ideą początkowo było kształcenie uczniów do godnego życia, które oznaczało połączenie rozwoju duchowego z naukowym (Wróbel-Lipowa, Ausz 2010: 19).

\section{Pijarzy w Polsce}

W Polsce szkoły pijarskie cieszyły się dużą popularnością, pierwsze próby sprowadzenia pijarów do Polski miały miejsce w 1633 roku. Kanclerz Jerzy Ossoliński udał się wtedy do Rzymu, aby złożyć hołd papieżowi Urbanowi VIII. Dzięki przychylności księcia Maksymiliana Dietrichsteina w czasie jego wizyty na Morawach powstał w Lipniku nowicjat pijarski. Po kontakcie Jerzego Ossolińskiego z Kalasancjuszem, a także z księdzem Mateuszem Judyckim, i uzyskaniu stosownych zezwoleń, postanowiono utworzyć na Pomorzu klasztor pijarski, remontując stary klasztor w Lęborku. Król Władysław IV poparł koncepcję sprowadzenia zakonników pijarskich na teren Polski, ponieważ mogliby oni stanowić alternatywę dla wszechobecnego zakonu jezuitów (Ausz 2013: 31). Jednak dotychczasowi właściciele nie chcieli zrezygnować z klasztoru, z tego względu sprowadzanie pijarów do Polski znacznie się przeciągnęło. Za sprawą sprowadzenia pijarów wstawił się Stanisław Lubomirski, starosta spiski, który przyczynił się do inauguracji nowego kolegium pijarskiego 10 grudnia 1643 roku. Samo kolegium otwarto jednak w lipcu 1643 roku. Polskie kolegia pijarskie aż do 1662 należały do prowincji niemieckiej, dopiero w tymże roku powstała odrębna prowincja polska zatwierdzona przez papieża Aleksandra VII (Ausz 2013: 24). Na początku działalności szkoły pijarskie nie odbiegały od innych szkół poziomem kształcenia. Zmieniło się to za sprawą reform Stanisława Konarskiego, które rozpoczęły tak zwany złoty okres zakonu pijarów.

Stanisław Konarski urodził się w 1700 roku w Żarczycach; gdy skończył 15 lat stał się absolwentem kolegium pijarskiego w Piotrkowie. Tam nauczył się łaciny i retoryki. Później wstąpił do nowicjatu w Podolińcu. Po ukończeniu dwuletniego nowicjatu, już w wieku 17 lat, rozpoczął swoją praktykę pedagogiczną, nauczając poetyki i retoryki. Collegium Nazarenum przekształciło się w międzyczasie, ale tuż przed przybyciem tam Konarskiego, z fundacji przeznaczonej dla kilkunastu zdolnych i ubogich chłopców, w szkołę dla arystokracji. W związku z powyższym program nauczania zbliżył się do popularnych wówczas akademii rycerskich. Konarski był tak zdolny, że po dwóch latach nauki powierzono mu funkcję nauczyciela w Collegium Nazarenum. W kolejnych latach praktykował także we Francji (Kurdybacha 1967: 584-586). Oprócz dużej wiedzy i zdolności Konarski miał więc także międzynarodowe doświadczenie, „obok rzadko spotykanej przenikliwości oraz dalekowzroczności spojrzenia dysponował także umiejętnością praktycznego rozwiązywania najtrudniejszych nawet dylematów. Z dzisiejszego punktu widzenia szczególnie poruszające w działaniach 
ks. S. Konarskiego było niezmordowane uczenie trudnej sztuki miłości Ojczyzny, czyli wyrzekania się egoizmu i prywaty na rzecz dobra wspólnego, podporządkowanego potrzebom kraju i narodu" (Wróbel-Lipowa, Ausz 2010: 22). Stanisław Konarski w reformie edukacji widział przyszłość młodzieży, czyli zmianę postaw i świadomości młodych Polaków. Zmianę tę Konarski chciał zacząć od kształcenia polskich magnatów i wyższych klas społecznych nowatorskimi metodami, co doskonale wpisało się w poglądy pedagogiczne tamtych czasów (Wróbel-Lipowa, Ausz 2010: 49).

W 1740 roku Konarski otworzył Collegium Nobilium, mimo znacznych problemów finansowych oraz deficytu pomocy dydaktycznych. W druku były wtedy jego dwa podręczniki dotyczące nauczania gramatyki łacińskiej i poprawiania błędów wymowy. Collegium Nobilium dzieliło się na pięć klas, jednak nauka w nich trwała osiem lat, ponieważ II, IV i V klasa były dwuletnie. Po ukończeniu cyklu ośmioletniego absolwenci mogli jeszcze uczęszczać na kurs prawa. Zajęcia były prowadzone głównie po łacinie, nie była ona jednak celem kształcenia (jak w innych szkołach tego typu), lecz język ten miał być środkiem do zrozumienia poszczególnych dziedzin. Podkreśla to postulat pijarski, że nauczanie miało mieć głównie charakter pragmatyczny. W miejsce zredukowanych godzin łaciny Konarski zaplanował takie przedmioty, jak: arytmetykę, języki obce, historię Polski i powszechną, fizykę, geografię czy filozofię racjonalistyczną. Nie bez znaczenia były także zajęcia związane z teatrem, odgrywał on ważną rolę w nauczaniu pijarskim. Z nauką języka francuskiego związane było oswojenie uczniów z wystąpieniami publicznymi, a służyć miał temu także teatr. W każdym kwartale wystawiano jedną tragedię w języku polskim i jedną we francuskim (Kurdybacha 1967: 191-194). Szkoły te miały kształcić w języku narodowym, łacina była potrzebna jedynie do rozumienia tekstów. Miano kształcić ludzi niebojących się wystąpień publicznych oraz oczytanych i mających chęć rozwoju, a przede wszystkim narzędzia do tego, żeby się rozwijać. Celem było: „wychowanie dobrego obywatela Polski szlacheckiej, który potrafiłby zachować to wszystko, co było w niej jeszcze zdrowe, a na miejsce przestarzałych praw umiał rozsądnie wprowadzać nowe" (Kurdybacha 1967: 597). Należy podkreślić, że przez „przestarzałe” rozumiano nieaktualne, prowadzące do uwstecznienia lub rozwoju lub nieuwzględniające współczesnych potrzeb prawa. Cechą charakterystyczną wychowania pijarskiego było też to, że przykładano ogromną wagę do kształcenia nauczycieli.

\section{Kształcenie w szkole pijarskiej}

Założyciel polecał stałe kształcenie się nauczycieli, udział w cotygodniowych konferencjach z udziałem prefekta, składanie sprawozdań przez przełożonych za każde pół miesiąca. Aby nauczyciele mogli sprostać tym wymaganiom, musieli nieustannie nie tylko się kształcić, ale również dbać o swoje zdrowie, zarówno psychiczne, jak i fizyczne (Taraszkiewicz 2015: 117). Charakterystyczne dla szkolnictwa pijarskiego było także tworzenie różnego rodzaju dzieł, takich jak: mowy, kazania, ody, sztuki teatralne, które 
przysłużyły się do rozwoju retoryki. Największym zainteresowaniem wśród nauczycieli pijarskich cieszyło się jednak zagadnienie edukacji - znaczący odsetek zakonników zajmował się oprócz pracą w szkołach pisaniem prac pedagogicznych (Taraszkiewicz 2015: 143). Do grona wychowawców oprócz nauczycieli należeli między innymi: prefekt odpowiadający za modlitwę, spowiednik, wychowawcy odprowadzający dzieci do domu po skończonych lekcjach, osoba przyjmująca interesantów, sekretarz, portier, prefekt oratorium szkolnego, bibliotekarz czy korektor. Co miesiąc w szkołach pijarskich odbywały się także akademie i uczniowskie popisy, które zwracały uwagę na postępy w nauce. Nauka w klasach kończyła się organizacją teatralnych przedstawień szkolnych. Innowacją były także kary cielesne stosowane wyłącznie w przypadku ciężkich przewinień. Wymierzał je przygotowany do tego egzekutor, który nie mógł bić po głowie ani okaleczać. Najcięższe przewinienia karane były usunięciem ze szkoły (Taraszkiewicz 2015: 27-29). Sam Konstancjusz opowiadał się jednak za metodami profilaktycznymi, które szczególnie współcześnie są bardzo ważne i popularne. Ponadto do karania mieli być powołani specjalni konsultanci spotykający się co tydzień, aby rozsądzać sprawy karania, tak by kary były jak najtrafniejsze. Metody miały być stanowcze, ale uprzejme, ponieważ ich celem miało być zapobieganie powstającym wśród uczniów buntom i przemocy fizycznej. W związku z tym nakładanie kary miało być z założenia pozbawione złości. Każdy uczeń znał więc reguły postępowania w danym ośrodku, które z zalecenia miały być powieszone blisko bramy wejściowej, tak aby każdy mógł się z nimi zapoznać (Taraszkiewicz 2015: 184). Jednak nauczanie pijarskie to nie tylko karanie, ale także nagradzanie. Codziennie rano, po pierwszym dzwonku, uczniowie zbierali się w klasach i zdawali relacje z wykonanych zadań wskazanych wcześniej przez nauczyciela. Najlepszy uczeń, zwany imperatorem, czyli cechujący się nie tylko dobrymi ocenami, ale także dobrym wychowaniem, wpisywał pozostałym oceny i decydował o tym, czy dany uczeń umie czy nie umie danego materiału. Nauczyciel po przejrzeniu wpisanych już ocen chwalił także dobrych uczniów i upominał tych, którzy opuścili się w nauce. Każda lekcja kończyła się modlitwą.

Oczywiście dokładny przebieg lekcji w każdej placówce pijarskiej różnił się od siebie, jednak sama struktura i założenia były podobne. Jeden nauczyciel wykładał w jednej klasie, co miesiąc przeprowadzano egzaminy sprawdzające wiedzę chłopców, potem co kwartał, a na koniec roku pisano jeden ogólny egzamin. Aby uzyskać promocję do następnej klasy, uczeń musiał zdać egzamin roczny przed wakacjami, czyli napisać pracę pisemną: exercitium de promotione (Taraszkiewicz 2015: 200-202). Pierwsze programy nauczania spisał sam Józef Kalasancjusz i oparte były o model humanistyczny, który już wówczas funkcjonował. Z upływem lat uzupełniano go o postanowienia kapituły generalnej, które brały pod uwagę współczesne potrzeby. Pijarzy, tworząc swoje placówki, chcieli uniknąć bezwzględnego respektowania zasad, jak miało to miejsce w zakonie jezuickim. Program kształcenia szkół w Polsce nie odbiegał także znacząco od idei szkół świeckich. Pijarzy zakładali głównie szkoły podstawowe, zwane elementarnymi, i średnie. Przyjmowano do nich dzieci bez względu na pochodzenie społeczne. Polskie szkoły pijarskie wykazywały się tolerancją, przyjmowano do nich 
innowierców i nie dyskryminowano ich w procesie rekrutacji. Podobnie nie przymuszano do zmiany wiary na katolicyzm. Początkowo założeniem zakonu było przygotowanie ubogiej młodzieży do samodzielnego życia. Przyjmowano ich na podstawie tak zwanego świadectwa ubóstwa wydanego przez spowiednika, ale już w 1617 roku zrezygnowano $z$ tego wymogu i szkoły otworzyły się także na rodziny szlacheckie, aby ich nie dyskryminować ze względu na stan społeczny. Nauczanie było zbiorowe, bezpłatne, ale także - co bardzo ważne - odbywało się w języku ojczystym. W każdej klasie mogło być jednak nie więcej niż sześćdziesięciu uczniów. Założyciel zadbał też o takie przedmioty, jak wychowanie fizyczne i higiena. Placówka musiała posiadać ogród i patio, a także dostęp do wody i toalet (Taraszkiewicz 2015: 181-184). Główną zasadą szkoły była ochrona dzieci przed demoralizacją przez zwalczanie analfabetyzmu. Tytuły honorowe uczniowie także uzyskiwali bez względu na pochodzenie społeczne. Przechodziły one co miesiąc na innych uczniów, tak aby żaden z dobrze uczących się nie był pominięty (Taraszkiewicz 2015: 211-212).

Bardzo ważnym aspektem szkoły pijarskiej był teatr szkolny. Początkowo zakazany on był przez założyciela, jednak w 1658 roku pijarska kapituła prowincjonalna prowincji niemieckiej i polskiej przekonała się, jak wielkie znaczenie ma teatr w kształceniu młodzieży i że jest traktowany jako skuteczny instrument dydaktyczny w zakonie jezuickim. W konsekwencji postanowiła, że pijarzy nie będą się wstrzymywać z założeniem własnego teatru. Ostatecznie dopiero w 1682 roku kapituła generalna pozwoliła uczniom brać udział w spektaklach teatralnych. Początkowo nakazano organizację przedstawień po łacinie, jednak później pozwolono na sztuki także w języku ojczystym. Teatr jezuicki powstał zatem wcześniej, bo już w 1566 roku; początkowo aktorami byli tylko uczniowie klas poetyki i retoryki, a więc klas starszych, jednak sztuki odgrywano wyłącznie po łacinie. Przedstawienia te miały miejsce głównie na uroczystościach szkolnych i miały pełnić funkcję umoralniającą i dydaktyczną. Dotyczyły one często kwestii religijnych, były to między innymi: dialogi pasyjne, pastoralne czy żywoty świętych. Autorami dzieł byli głównie nauczyciele retoryki. Właśnie od jezuitów początek wziął teatr pijarski i znacząco się upowszechnił. Ponadto: „scena szkolna odgrywała ogromną rolę w ogólnej edukacji językowo-retorycznej, ponieważ kształciła umiejętności krasomówcze, wyrabiała odwagę konieczną przy publicznym zabieraniu głosu, była też okazją do sprawdzenia postępów w nauce i pewności siebie. Nadto uczeń zdobywał umiejętności posługiwania się mimiką i gestem, doskonalił dykcję, rozwijał pamięć, wzbogacał słownictwo" (Taraszkiewicz 2015: 224-229). Powyższy cytat świadczy o ogromie funkcji, jaką pełnił teatr pijarski, i różnorodności umiejętności, jakie pozwalał uzyskać. Tematem sztuk były nie tylko aspekty religijne, ale często były to tematy z zakresu literatury klasycznej lub dotyczące współczesności. Do czasu reformy Konarskiego sztuki dotyczyły głównie tematyki historycznej, nie przekazywały jednak wiedzy historycznej, ale ukazywały elementy wychowawcze, wskazując na sukcesy człowieka, który jest dziełem Boga (Taraszkiewicz 2015: 233-240). 


\section{Zakończenie}

Działalność pijarska była wyjątkowo innowacyjna, głównie ze względu na podmiotowe podejście do wychowanka oraz łączenie wychowania moralnego z nauczaniem. Służyła ona poprawie życia dzieci i młodzieży pozbawionej z powodu ubóstwa szans na inną formę edukacji. Edukacja skierowana początkowo do ubogiej młodzieży z czasem przekształciła się w szkolnictwo elitarne, jednak założenia organizacyjne, metody i formy pracy wychowawczej oparte na demokracji pozwoliły stworzyć ponadczasowy model pracy z młodzieżą.

\section{Bibliografia}

Ausz M., 2013, Odbudowa polskiej prowincji pijarów. Działalność wychowawczo-edukacyjna zakonu w latach 1873-1918, Lublin.

Ausz M. (red.), 2013, Z historii polskich pijarów, Kraków.

Kurdybacha Ł. (red.), 1967, Historia wychowania, Warszawa.

Puchowski K. (red.), 1996, Szlakami przeszłości i czasów współczesnych, Gdańsk.

Taraszkiewicz J., 2015, Pierwsze stulecie zakonu pijarów na ziemiach Rzeczypospolitej Obojga Narodów, Gdańsk.

Taraszkiewicz J., 2011, Edukacja historyczna w szkolnictwie pijarskim w Rzeczypospolitej 1642-1773, Gdańsk.

Wróbel-Lipowa K., Ausz M. (red.), 2010, Szkolnictwo pijarskie w czasach minionych a współczesne problemy edukacji historycznej, t. 1-2, Kraków-Lublin.

\section{Biogram}

Katarzyna Semrau - Uniwersytet Gdański, Wydział Nauk Społecznych, Instytut Pedagogiki. Zainteresowania naukowe: zakon salezjański, pedagogika świętego Jana Bosco, zakon pijarów, historia katechezy, uzależnienia behawioralne, uzależnienia od środków psychoaktywnych, uzależnienia od nowych technologii. Specjalista psychoterapii uzależnień. 